\title{
Addressing the biblical and ecclesial obligation of Nigerian Roman-Catholic priests in promotion of peace and social justice
}

\begin{tabular}{|c|c|}
\hline \multicolumn{2}{|c|}{$\begin{array}{l}\text { Authors: } \\
\text { Oguejiofo C. P. Ezeanya }{ }^{1,2,3} \text { (1) } \\
\text { Benjamin O. Ajah }{ }^{2,3} \text { (I) }\end{array}$} \\
\hline \multicolumn{2}{|c|}{$\begin{array}{l}\text { Affiliations: } \\
\text { }{ }^{2} \text { Department of Religion and } \\
\text { Cultural Studies, Faculty of } \\
\text { the Social Sciences, } \\
\text { University of Nigeria, } \\
\text { Nsukka, Nigeria }\end{array}$} \\
\hline \multicolumn{2}{|c|}{$\begin{array}{l}{ }^{2} \text { Department of Sociology } \\
\text { and Anthropology, Faculty } \\
\text { of Social Sciences, University } \\
\text { of Nigeria, Nsukka, Nigeria }\end{array}$} \\
\hline \multicolumn{2}{|c|}{$\begin{array}{l}{ }^{3} \text { Department of New } \\
\text { Testament and Related } \\
\text { Literature, Faculty of } \\
\text { Theology, University of } \\
\text { Pretoria, Pretoria, } \\
\text { South Africa }\end{array}$} \\
\hline \multicolumn{2}{|c|}{$\begin{array}{l}\text { Corresponding author: } \\
\text { Benjamin Ajah, } \\
\text { okorie.ajah@unn.edu.ng }\end{array}$} \\
\hline $\begin{array}{l}\text { Dates: } \\
\text { Received: } 135 \\
\text { Accepted: } 23 \\
\text { Published: } 08\end{array}$ & $\begin{array}{l}\text { ept. } 2021 \\
\text { Dct. } 2021 \\
\text { Dec. } 2021\end{array}$ \\
\hline \multicolumn{2}{|c|}{$\begin{array}{l}\text { How to cite this article: } \\
\text { Ezeanya, O-C.P. \& Ajah, B.O., } \\
\text { 2021, 'Addressing the biblical } \\
\text { and ecclesial obligation of } \\
\text { Nigerian Roman-Catholic } \\
\text { priests in promotion of } \\
\text { peace and social justice', } \\
\text { HTS Teologiese Studies/ } \\
\text { Theological Studies 77(4), } \\
\text { a7138. https://doi.org/ } \\
\text { 10.4102/hts.v77i4.7138 }\end{array}$} \\
\hline \multicolumn{2}{|c|}{$\begin{array}{l}\text { Copyright: } \\
\text { (c) 2021. The Authors. } \\
\text { Licensee: AOSIS. This work } \\
\text { is licensed under the } \\
\text { Creative Commons } \\
\text { Attribution License. }\end{array}$} \\
\hline \multirow[b]{2}{*}{ 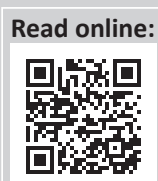 } & \\
\hline & $\begin{array}{l}\text { Scan this QR } \\
\text { code with your } \\
\text { smart phone or } \\
\text { mobile device } \\
\text { to read online. }\end{array}$ \\
\hline
\end{tabular}

Some of the Nigerian Roman-Catholic priests had been murdered by armed criminals in the presbyteries on account of their witnessing to the gospel truth. Others have continued to receive threats of molestation and death for the same reason. This necessitated the current study that adopted an etymological approach and secondary sources of data, such as journal articles, newspaper publications and policy briefs, to discuss on how to address the biblical and ecclesial obligation of Nigerian Roman-Catholic priests in promotion of peace and social justice.

Contribution: The article provides that the target of the Nigerian Roman-Catholic priests was not just to console the dejected of the society over the neglect of the leaders but include the thrust of actions that would get both the leaders in the government and the populace to know their respective duties and be compelled to do them.

Keywords: biblical and ecclesial obligation; Nigerian Roman-Catholic priests; peace; social justice; violence.

\section{Introduction}

The need for Roman-Catholic priests to help in ensuring peace and social justice cannot be overemphasised (Ajah 2018:13; Akasike 2018:2; Akubo 2018:5). People generally look to RomanCatholic priests to be the voice of the voiceless in matters that have become very difficult to manage, such as for promotion of peace and justice in social settings, like Africa, where people have been grossly denied their rights and the law seems to be helpless in the hands of the protectors and defenders (Ajah et al. 2021:4; Anthony et al. 2021:1).

Promotion of peace and social justice is an apostolic and ecclesial demand on the ministry of the priest (Otu, Nnam \& Uduka 2018:7). As an ecclesial demand, the whole world, irrespective of different religious orientations of the people, looks for the intervention of the priest who is taken to be a religious leader, over the circumstances of the world that stifle peace and social justice. As an apostolic demand, the spirit of the Word of God as regards the Messianic Mission of liberating people from the bondage of various kinds invites the priest, who is also ordained to the ministry of the Word to be a true disciple of the Word of God in the scriptures. The Church, which is the sacrament of Christ, calls on the priest to embrace the promotion of peace and social justice as a major aspect of his vocation in line with the mission of Christ whose ambassador he is (Ajah, Dinne \& Salami 2020b:3; Enweonwu et al. 2021:3; Okpa, Ajah \& Okunola 2018:8; Rahman \& Khambali 2013:9).

Peace does not merely mean the absence of war. Rather, peace is built on four foundations, namely truth, justice, love and liberty (Suleiman 2016:9; Ugwuoke, Ajah \& Onyejegbu 2020:8; Zenn 2017:2). These ingredients of peace may not be overlooked in the search for peace. Justice in a similar way transcends merely giving an individual their due, but also includes respecting their rights and protecting their proprietary interests (Ajah \& Okpa 2019:13; Ajah et al. 2020c:7; Eze, Obi \& Ajah 2020:2; Nnamani et al. 2021:8). These later aspects of peace and social justice are often the most neglected and abused and in need of protection. The intention of this study was to address the call of the Catholic church on priests to ensure the triumph of peace and social justice as part of their ministerial duties, in line with their status as another Christ.

\section{Etymological elaboration}

The word obligation is etymologically derived from two Latin words $o b$ [on account of] and ligare [ligo, ligare, ligavi, ligatum, to bind, to tie together]. Obligare, therefore, means indebtedness 
placed on somebody on account of something, which has both moral and legal quality. It cuts across both spiritual and temporal realms to bind the person involved with a compulsion to satisfy a given circumstance. Whenever a valid contract is established, the parties to the contract are assessed by their sensitivity to the element of obligation (ed. Arinze 1990:15; Sagay 2000:47). The Code of Canon Law in Canon $287 \S 1$ placed on priests a perpetual duty to always do their utmost to foster peace and harmony among people based on justice (Ezeanya 1998:18; John 1992:2). This duty has an obligatory character and should always be understood as such. St. Paul said:

If I preach the gospel, this is no reason for me to boast, for an obligation has been imposed on me and woe to me if I do not preach it! (1 Cor 9:16)

The scripture ( $\operatorname{Rm} 10: 15)$ also said ' $[h]$ low beautiful are the feet of those who bring the good news!'

The contextual use of the term 'priest' came from the Hebrew (zaqen), old man, and the Greek 'presbyter' (presbyter), elder (Ezeanya 1998:3; Nnam et al. 2019:9) even as the Hebrew Kohen is the literal interpretation of priest. The elders of these cultures were considered to be custodians of the law and morality of the people and intervened in matters of religion and civil conflicts on behalf of the gods. In Nigeria, the priest is always called Father for the father figure he represents among them. A person is identified as a father not necessarily for being elder to others but for the relationship of his inherent role of authority with divine wisdom and authority. Hence, the Igbo of Nigeria would proverbially say 'anaghi enwe nwata udene ebe ha ncha bucha isi-nkwocha' [there is no baby vulture as all of them are bald haired], indicating that every priest, young or old, is an elder. The grey hair of elders to whom priests are associated was taken to be a sign of favour from the gods who granted them longevity as a consequence of probity of life to become a link between the old and new generations (Ezeanya 1998:3; Nnam et al. 2019:5). Hence, they were equipped to adjudicate the disputes among the people with complete fairness and ensure the reign of peace. A priest is therefore a spiritual link between God and his people, the dispenser of social justice, and the custodian of public conscience (Ajah \& Onyejegbu 2019:2; Enweonwu et al. 2021:8; Ezeanya 2014:17). The word priest has more than one usage in the context of theology. In the Ancient Near Eastern civilisation, the hereditary priesthood was fashionable whereby a class of people were provided some roles to play on behalf of others for the common good, which included diviners, magicians, scribes and teachers (ed. Nwaigbo 2000) In the Old Testament, the Levites were of the priestly class that performed the sacrifices of the sanctuaries and other communal sacrifices. In ancient Nigerian cultures, the priests functioned as fortune tellers, diviners and removers of ancestral curses (Ezeanya 2014:10).

The gospels have a derogatory view of the Levitical priesthood. Jesus referred to their office to decide between what is clean and unclean (cf. Mt 8:14; Mk 1: 44; Lk 5:14;
17:14), and vindicated freedom of action from them on the Sabbath, insisting that priestly privileges must yield to human needs (cf. Mt 12:4; Mk 2:26; Lk 6:4), even the parable of the good Samaritan contains an implicit criticism of the priests and Levites (cf. Lk 10:31ff.). Jesus, therefore, applied the term priest neither to himself nor to his disciples. The passion narratives imputed the priestly aristocracy with the greatest malevolence of cooperating and insisting that Jesus be put to death (Akukwe 1988:11; Ezeanya 2018a:14).

The application of the term priest in the New Testament came first in the context of the Christian community (cf. $1 \mathrm{Pt}$ 2:5; Apoc 1:6; 5:10; 20:5.) whereby believers in Christ were seen as the new Israel of God, and therefore, a kingdom of priests (cf. Ex 19:6) to God. This defines the priesthood in the context of election and consecration (Suleiman 2016:1). The letter to the Hebrews dwelt very much in the priesthood of Jesus, which contrary to the Levitical heredity of the Jewish tradition came directly from heaven in the order of Melchizedek, and hence, superior to the Levitical order since Abraham, the father of both Levi and Aaron (ancestors of the priests), acknowledged the superiority of Melchizedek and offered tithes of all he had to him (cf. Ps 110:4; Heb 5:6, 10; $6: 20 ; 7: 1-17)$

As it is the duty of priests to offer sacrifices, Jesus the high priest of the new dispensation offered the supreme sacrifice of his own body and blood for the salvation of the world. This cancels the ancient sacrificial cult of the old dispensation (Cf. Heb. 10:1-12). Those who are baptised in Christ, therefore, became priests with him in his prophetic and royal mission (John 1992). Some are, however, ordained to minister in the person of Christ (in persona Christi Capitis) who is the head of his body, the Church (Okpa et al. 2018:13). According to the encyclical 'Mediator Dei' of Pope Pius XII:

It is the same priest, Christ Jesus, whose sacred person his minister truly represents. Now the minister, by reason of the sarcedotal consecration which he has received, is truly made like to the high priest and possesses the authority to act in the power and place of the person of Christ himself (virtute ac persona ipsius Christi). (Okpa et al. 2018:13)

The priest of the context of this research is mainly the one of the latest meaning that is N.T ministerial priests of the Catholic Church. It embraces Bishops and Presbyters ordained as ministers of the Word of God and the sacraments. It does not necessarily imply the common priesthood of all the baptised nor the ancient or O.T. priests.

\section{Ingredients of peace}

The Hebrew פורָש (shalom), which informed the Greek irene, and the Latin pax, is interpreted in English as peace, wellbeing and health. Etymologically, it signifies wholeness, completion, perfection and, indeed, a situation where nothing good is lacking (Areh, Onwuama \& Ajah 2020:7). Shalom was, therefore, used as a form of greeting, which carries with it the wish of total and holistic goodness devoid of any form of oppression, injustice or emotional discomfort. 
That is the peace which clerics are expected to promote. The messianic expectation of the people of Israel was that when the messiah comes:

$[H]$ e shall judge between the nations, and impose terms on many peoples. They shall beat their swords into plowshares and their spears into pruning hooks; one nation shall not raise the sword against another, nor shall they train for war again. (Is 2:4)

This setting ensures peace from the physical point of view.

The financial and diplomatic costs of wars have made this type of peace available to so many people; however, the same people under this umbrella of peace still experience a great lack of inner fulfilment and real peace (Ajah et al. 2020b:3). Peace does not only mean the absence of violence but also involves both external and internal harmony and satisfaction. Many situations can rob people of peace even when there seems to be calmness everywhere. Unjust political structures, lack of essential facilities and infrastructures of living, environmental degradation, and infringements on people's rights and freedom can militate against peace in the form of a cold war or battle without weapons (Ajah \& Ugwuoke 2018:5; Ajah et al. 2020b:9).

'Honesty, discipline in work, and attention to the weak' have been identified as the three ingredients of peace and joy in the society. Peace is, therefore, viewed in the holistic context of mind, soul and body, the denial of any of which could lead to conflict of one form or another. The mission of promoting peace by the priests, therefore, tallies with the view of the Second Vatican Council that:

[T]he joy and hope, the grief and anguish of the men of our time, especially of those who are poor or afflicted in any way, are the joy and hope, the grief and anguish of the followers of Christ as well. (Ezeanya 1998:3)

This is of paramount importance in Africa where sociopolitical difficulties and their contingent problems plague the continent with great lack of peace and call for an urgent attention.

\section{Conflicts and social justice}

The term conflict is derived from the Latin word confligo (confligo, confligere, conflixi, conflictum - to throw together, to clash). A stronger form of this root verb is found in conflicto, conflictare, conflictavi, and conflictatum - to strike violently, to collide with. It explains the pain of being troubled grievously, being harassed or tormented. The Latin situs $-a-u m-$ means situation or position (Ajah, Ajah \& Obasi 2020a:7).

The conflict, therefore, embraces all the things prompting sighs, which were enumerated under 'peace' above, and in addition, it includes other proven external concrete cases of disturbance and violence both of sociopolitical or religious origin and ideology and by neglect of duty. Akukwe (1988) noted that conflict situations highlight the problems being faced with, and which go contrary to integral human development for which the priests should be set to solve rather than being silent. They are problems of both religious and temporal or material order.

Communal squabbles over land acquisition, certain cultural practices that breed divisions among members of a community, inter-communal clashes over one thing or the other, neglect in the provision of essential amenities by government, insensitivity to the plight of prisoners and other less privileged members of the society, manoeuvring of the people's franchise at elections and at other forums of decision-making, and other cases of uncomfortable conditions of living constitute the conflict situations that are peculiar to African societies (Ajah \& Okpa 2019:1; Ajah et al. 2020c:4; Eze et al. 2020:3; Nnamani et al. 2021:7). They also form part of the distractions to peace, which the priests are challenged to confront in the spirit of the gospel message of witnessing to the truth.

The Latin word justitia, which is translated in English as justice, is understood in the biblical languages in the contexts of judgement and righteousness (Eze et al. 2021:4; Onyejegbu et al. 2021:7). Its basic meaning appears to be best when applied to the different objects or actions for which the element of fairness or equity is highly desired. Hence, one may talk of a righteous weight to mean the justice needed in measuring with equity or fairness (cf. Dt 25:15; Lv 19:36; Job 31:6; Ezk 45:10), or a right path to mean the path of justice (cf. Ps 23:3). As applied in common usage, justice goes with legal processes whereby judges adjudicate over various issues without partiality (cf. Lv 19:15; Dt 1:16).

Distortion of law is viewed as throwing of justice to the ground (Am 5:7), and the perpetrators turn the sweet fruit of justice into poison (Am 6:12). People's claim to right is, therefore, a justiceable cause (Nnamani et al. 2021:5).

Justice has further been divided to cover different aspects of human endeavour. Within the confines of the social teaching of the Church, there are three types of justice: commutative justice, distributive justice and social justice:

Commutative justice calls for fairness in transactions between individuals and groups in a just community. Distributive justice demands a just distribution of our natural resources, wealth and power, so that the basic material needs of each member of the community might be catered for. Social justice asks the individual to seek for what is necessary for the common good of the society. (Ajah 2018:53)

Social justice as a concept is etymologically derived from the הקרצ Hebrew word (sadeqeh):

$[W]$ hich in Greek is represented as dikaiosune, meaning style of action in relation to partnership with others. It entails the justice that regulates the norms of action guiding inter-human relationships. Also קרצ (sadeh) is used to signify: 'To let the innocent have his due', to 'justify him', while טפשמ (mispat) is used to indicate the yardstick for social justice for the lovers of peace, as exemplified in Ezekiel 18:5-9. Hence social justice entails both the respecting of other people's due and the conducting of one's self in a gentle manner. (Ezeanya 1998:4) 
People often experience many anomalies in the human society because of the differences in people's nurture, volition and sociopolitical and economic orientations and ambitions. Yet, as no man is an island, people have to put up with certain dispositions in order to exist in the human society. Several approaches to life have been classically propounded as ways of keeping one's head cool in the face of social injustice. According to Akukwe, 'the human soul in contemplating the future is filled with worry and deep sadness. The dog lying sleepily in the sun does not worry' (Akukwe 1988:32), and he, therefore, propounded the philosophy of sleep as the solution to every occasion of worry and maintained that sleep is the most delicious ditch in life's feast.

Agnostic fatalists resign to fate in whatever they encounter. They even discourage any human recourse to God, saying that man only tries to take refuge from the glaring realities of pain and suffering in the world by hiding under the shadow of a father figure (God) whom he (man) has created. They, therefore, suggest a total and constant resignation to fate in every situation with the disposition of 'if a bullet is destined for my head I will surely get it, if not I cannot get it; therefore, why worry?' (Ezeanya 1998:41). With this frame of mind, they are care-free over whatever happens around them. The above dispositions to social anomalies seem to foster peace, yet the man dies in all who keep silent in the face of tyranny. When the man dies in those who do not want to confront social ills what remains is moving carcass and not the human. A social injustice is then defined as 'a condition affecting a significant number of people in ways considered undesirable, about which it is felt that something can be done through collective social action' (Nnamani et al. 2021:14). To shy away from the responsibility of effecting the social action is cowardice, and the peace provided by such a resignation is lame.

Along the same vein, social justice may be viewed as any of the various professional or organised actions geared towards redressing or treatment of social problems, especially in the underprivileged classes. It is the sanitisation of the social order for the reign of justice, peace and tranquility, and the respect and protection of individual and collective rights of persons both physical and juridical (cf. Canon 96-123).

\section{Causes of discord and conflicts}

Several causes occasion discord and conflict as have earlier been mentioned, yet the causes may not easily be exhausted, as there are more causes than the discord and conflict they ignite. If one asks Igbo elders in Nigeria about discord or conflict, they may not end the discussion without discouraging you from any act that will engineer conflicts. They always added that $O$ bu ndi ahughi agha na-asika a nuo agha [it is only those who did not experience the war who propose war for whatever reason] (Achunike 2008:3). In this way, they condemn conflicts that might lead to the outbreak of war. The war they always referred to is the Nigeria-Biafra civil war, which took place from 1967 to 1970 (30 months in total). This aroused the interest in investigating into some of the many causes of the war for a comparative analysis of the progression of conflicts from micro- to macro-consequences.

Emeka Odumegwu-Ojukwu wrote a book titled Because I am Involved, in which he tried to excavate the development of the roots of conflict which if not removed may make a mess of every effort at a peaceful coexistence (Ezeanya 1998:25; Odumegwu-Ojukwu 1989:37). He acknowledged the popular belief that part of the problems of the Nigerian disunity and conflicts is the great divergence of the ethnic groupings that make up the entity called Nigeria, yet he sees that recourse as a 'simplistic recourse' and showed how several countries with divergent ethnic groups, such as the United Kingdom, Soviet Union, United States of America, Cote D'Ivoire, Cameroon and others, had actually utilised the advantage of multi-ethnic groupings to rise to greater heights (Ezeanya 1998:8; Odumegwu-Ojukwu 1989:14). He therefore threw back the blame to what Nigerians had performed with the multi-ethnic groups, which has become a reality of their make-up.

Ojukwu traced the Nigerian conflict to the imperialism of the colonial masters who forced a castrated and impotent leadership on Nigeria, with the aim of perpetuating their colonialism in the country. The different ethnic groupings were either disrobed of their already viable leadership structure that ensured peace and progress and clothed with artificial mediocre leadership, or influenced with loose life novelty or religious acrimony that seeks only the good of their clients, and in general, the seeds of tribalism and dichotomy were planted among the people, which flourished in a vehement hatred for one another and a wrong orientation on their abilities and ambitions (Ezeanya 1998:8; OdumegwuOjukwu 1989:13). Elites were made champions of their particular ethnic interests, such that the more hatred a person showed to people of another ethnic group the greater hero he was made by his own ethnic group. Mutual suspicion and fear of the activities of the other became engraved in the hearts of Nigerians. Any innovative vision or meaningful progress is first of all weighed along the ethnic line of origin before it can be applauded and accepted or bedevilled and attacked (Ezeanya 1998:8; Odumegwu-Ojukwu 1989:15). The cancerous conflicts of the Nigerian disunity and bitterness are therefore vestiges of neo-colonialism, which may be seen as:

[T] he collusion and compromise between foreign imperialists, and a section of native comprador bourgeois and reactionary elements, to maintain colonial rule under new forms and methods, whilst checking and opposing the movement of the broad masses. (Ezeanya 1998:13; Odumegwu-Ojukwu 1989:2)

From a psychological point of view, violence is considered a 'normal' feature of the human society (Nnamani et al. 2021:7). As it has become part of our everyday life, we experience cases of assassination, bombings, kidnappings and the like. Such events are ordinarily best attended to with people's manifestation of indignation, chanting of slogans to register their disgust, diplomatic statements from world leaders in the guise of expressing sympathy, while waiting for the 
passage of time for the event to be forgotten and be relegated to the archives of history. According to Ajah et al. (2020b), the externally manifested acts of violence are just the tip of the iceberg' for which the actual root causes need to be discovered. A similarity is identified between the so-called lower animals and humans in the question of violence, but as in the animals the instinct is for self-survival, while in humans it has a multidimensional root and complex:

While man as a biological animal shares in the instincts of the lower animals, there are however certain passions which are exclusively human, such as, love and compassion, hatred and sadism, etc. It is these deeply rooted passions in the human constitution which find expression either in positive acts of love or, if abused, in the acts of calculated violence and destruction. (Ezeanya 1998:27)

Family nurture is also a cradle for sowing the seeds of violence. 'Pampered children do not develop social feelings; they become despots who expect society to conform to their self-centered wishes' (Ajah \& Ugwuoke 2018:7). Media outfits through unhealthy communications also sow the seeds of violence as Pope John Paul II rightly remarked that:

$[I] \mathrm{t}$ is a fact that truth serves the cause of peace, it is also beyond discussion that non-truth in all its forms and at all levels: lies, partial or slanted information, sectarian propaganda, manipulation of the communications Media - goes hand in hand with the cause of war. (John Paul II 1995)

False elitism through racist activities, as in the case of Hitler and his 'pure race' trajectory, also promotes conflicts and discord. The same is the case with different forms of economic exploitation and the struggle to safeguard one's belongings and rights (Okafor \& Onebunne 1996:13). All these lead to violence and climax in wars and loss of human life and property. Sociopolitically, the conflicts and discord born of the above-mentioned factors are manifested in civil and international unrests and wars, while religiously they rear up their heads in religious and, or denominational intolerance, lack of missionary cooperation among members of the same denomination, together with the 'son-of-the-soil' syndrome, which plagues many Local Churches in Nigeria today.

\section{Effects of unjust structures}

Any society that has its structures built on the columns of injustice and conflict is like the mansion resting on sand for its foundation and is bound to collapse (Iheanacho 2009:13; Muhammed, Ismaila \& Bibi 2015:8). Injustice is like a time bomb that explodes on saturation irrespective of the seeming comfort of the possessor, and a conflict situation is an evil wind that blows no one to any good fortune if fanned into flame. They, therefore, have to be nipped in the bud for peace to reign (Eze et al. 2021:7; Ugwuoke et al. 2020:4). Ayi Kwei Armah in a book titled, The Beautiful Ones Are Not Yet Born used the story of the life of 'The Man' to present the woeful condition of the ordinary man in an unjust and corrupt African society. The character called 'The Man' is the silent type (Armah 1975). Although educated and employed in the Railway Corporation, he was regarded as stupid and primitive because he remained abjectly poor as he decided not to indulge in the wave of bribery and corruption that characterised the social life of the people (Armah 1975).

'The Man' could not earn a comfortable living and was in constant repugnance of his family members and corrupt colleagues who saw no virtue in isolating himself from what was in vogue in the whole society (Armah 1975). Honesty in work would only ensure the promise of salary payment, which may not be forthcoming. The setting presupposes that the worker has to enrich himself with bribes from clients or customers who had also been disposed to the understanding that no services could be given to them unless they bribed the workers. Customers who ordinarily presented bribes to 'The Man' before negotiating their business were scandalised by his refusal of the offer, and wondered how he could make it in the circumstances of the society (Armah 1975).

Filth and decay filling up everywhere in the society represented the effects of corruption and challenge purists who want a corruption-free society. The fate of such purists was represented by Armah as frustration and unrewarding efforts. Corrupt people amass public wealth and live in affluence, exploiting all the goodies of the society and having all the 'society ladies' at their beck and call, while the less privileged ones wallow in abject poverty, addiction to drugs and other dirty activities to distract themselves, and those who could bear the cross no more took to suicide (Armah 1975). Armah's work ended on a note of pessimism, which the title also represented. By saying that the beautiful ones are not yet born, which was the inscription on the bus that engaged the Man's thought for a protracted time, Armah implied that with the level of corruption in Africa those who can have both the determined spirit to fight it and the facilities, energy, societal support, trust and authority to penetrate the structures of the society to effect those basic ingredients of justice are not yet foreseeable (Armah 1975).

Elections are often taken to be the time the people exercise their right of choosing their leaders; however, in Africa any other name suffices for the process of getting people into government offices but election (Ugwuoke et al. 2020:9). The political statement of Abraham Lincoln that 'no man is good enough to govern another man without his consent' does not apply in Africa. Rather than a democratic government what is found in Africa is an authoritarian government, or at best, a rule by civilians but not a democratic one. In a democratic government, the people rule themselves through election of those to be in office, while in the authoritarian government some little group of the populace seizes power and impose themselves on others and begin to dictate to them as their leaders. This is only possible when the sociopolitical structure is corrupt (Armah 1975).

To avert the critical look of the international community that prescribes democracy for all some dictators arrange general elections but manipulate all the activities of the elections from the beginning to the end (Obegolu 1999:8). The voters' 
registration accommodates names of dead and non-existent people being forwarded by the corrupt politicians, including names of cattle and trees. In a society with unjust structures, any conceivable thing can happen and nobody is held responsible. Such a society can rightly be described as a land of unlimited possibilities. The hopelessness of living under such a setting, full of injustice and seeming to have no prospect for secure recourse, could really be endemic.

\section{Meeting the priestly obligation}

Culture clash between the colonial heritage and the traditional heritage of the Africans is one of the chief sources of conflict (Zenn 2017:2). A formidable approach to correcting this anomaly by priests is found to be visible in the campaign of Monsignor Martin Okeke Mmaduka who challenged the world with the need for inculturation for freedom from imperial bondages in both the church and the state. In the life activities of this great Igbo priest of Nigeria, we view a novelty in the priestly activity at effecting change to the status quo through some social actions that generated many controversies in the midst of the people who witnessed his works (Ezeanaya 1998:13; Okafor \& Onebunne 1996:8). The life activities of Msgr. Mmaduka is today presented as a model of African inculturation through deeply religious and Christian orientation, which courageously challenges the negative elements of the society and indefatigably upholds and advances the good elements of culture that had been bedevilled by the wrong approach of the expatriate missionaries who brought the good news of faith to the African soil (Ezeanaya 1998:12; Okafor \& Onebunne 1996:7).

Msgr. Mmaduka carefully stripped the gospel message of its European garment in the African soil and clothed it with beautiful African regalia. He was able to sustain the hazards such a venture presented, as he laid the foundation of the inculturated and incarnational theologising in Nigeria. The Second Vatican Council later acknowledged the need to 'adapt' the gospel message to each cultural context without any form of watering down of the message or imposing a foreign culture on others in the name of giving them the good news (Ezeanaya 1998:13; Okafor \& Onebunne 1996:11). The zeal for God's work led Msgr. Mmaduka to conversion from the Traditional Religion to Christianity, and then to the Catholic Priesthood. His crusade for the correction of the social anomaly of the faith praxis at that time started when he finished his studies in Rome where he was treated as a beast because of his colour and race (Ezeanaya 1998:14; Okafor \& Onebunne 1996:11). On his return home, he discovered that the same propaganda was being carried out in his country by the expatriate missionaries in the guise that several cultural activities of African origin were regarded as bad and diabolic, while the similar ones of European origin were sampled as angelic and objects of salvation. He, therefore, saw the need for correcting the misconception and extricate such indoctrination from the minds of his people. This gave him an ocean of difficulties to surmount, especially as he was fighting alone and was misunderstood even by his fellow priests and superiors both expatriate and native (Ezeanaya 1998:13; Okafor \& Onebunne 1996:11).

Three aspects of culture: language, food and dress, were found by Msgr. Mmaduka as key elements of the inculturation of the gospel message in the spirit of the Incarnation. Christ spoke the language of his people, ate their food and dressed like them (Ezeanaya 1998:13; Okafor \& Onebunne 1996:12). Why then would the Mass and other sacred liturgical activities of the Church be performed in Latin? Why should the food of his people, like pounded fufu and other local delicacies, not be cooked and enjoyed in the presbyteries? Why prefer the soutane or the Roman collar dress to the ordinary African wear, which demystifies the ministers of the gospel in the sight of the people and allows for the triumph of the message of Christ rather than the person of the minister? He therefore went about with his campaign in words and deed amidst untold oppositions. He championed the arduous translation of the Latin-English Missal into Igbo language, ate the Igbo native food and wore Igbo traditional garments rather than the soutane (Ezeanaya 1998:14; Okafor \& Onebunne 1996:12).

In his pastoral work, Msgr. Mmaduka insisted on reviving the cultural activities already destroyed and buried by the expatriate missionaries as satanic and leading to damnation. He gave back the cult of the masquerade its entertaining value rather than ban it to Christians as devilish as the missionaries taught. He joined the traditional dances of the celebrating natives despite the dichotomy placed between the Christians and the Traditional Religionists, confining the latter to hell fire as followers of Satan, and therefore, banning Christians from having any fraternal dealings with them (Ezeanaya 1998:14; Okafor \& Onebunne 1996:12). Moreover, more than any other pastor of his time he was very keen at discovering certain cultural activities that actually spelt of idol worship and vigorously fought and converted the believers from such practices. This explains his focus and vision for the crusade. Before his death, he made a will that charitably distributed all he had and requested that he be spared 'great men's burial', instead, that he be buried without delay once he died and in his home town instead of the Cathedral burial ground where priests have a common burial ground. His wishes were adhered to as much as possible, and his fame and crusade gained more popularity and disciples after his death (Ezeanaya 1998:13; Okafor \& Onebunne 1996:11).

The landmark left by the activities of Msgr. Mmaduka provided a turning point and great inspiration to the activities of Awka diocesan priests who have him as a member of their priestly fraternity and a noble elder brother, and many other priests from other dioceses that see in him the mentorship for African Christian renaissance for social justice (Ezeanaya 1998:14; Okafor \& Onebunne 1996:12). Following his example, and with the encouragement of the Universal Church that today longs for inculturational and contextualised theologising, the priests of Awka diocese now champion other facets of the social justice question. 
Msgr. Mmaduka fought alone and wrote his name in gold, and now that his campaign has been understood and received Institutional and Hierarchical kudos from the Church, his younger brothers in the priesthood are very determined to take the campaign to its logical conclusion. That is why today many cultural activities are welcome in the church unlike before, and great understanding developed between traditional cultural activities and the Christian life and call to holiness.

Frontline renewals in the church are vigorously pursued in the church today for a better relevance of the church in the world of conflicts and rancour. Some prominent Catholic priests and theologians, such as Hans Kung, Lavinia Byrne, Charles Curran, Jeanne Gramick, Robert Nugent and Tissa Balasuriya, were in focus with the Vatican over their teachings and ministry in the Catholic Church (Collins 2001; Dorr 1991). These scholars felt the need that the Church has to be more democratic in the assessment of the scholarly and pastoral contributions of experts to the growth of the Church. They compared the activities and approach of the obsolete Congregation of the Roman Inquisition with the present-day Vatican Congregation for the Doctrine of the Faith (CDF) and felt that there are many similarities (Collins 2001; Dorr 1991). The Inquisition, over the ages, was indicted of severing social justice by not allowing the accused the right to fair hearing and trial, instead, accusations were trials, and the accuser was the judge of the accused as well. In that set-up, peace continued to elude the people so that tension and a sense of insecurity filled the atmosphere (Collins 2001; Dorr 1991).

The struggle is quite unique in the sense that a group of experts gathered to provide a collective testimony of the need for greater social justice accorded to the freedom of conscience and expression of expert thought, especially from the ecclesiastical institution. The fact that the principal actors in this struggle for freedom are not molested by the ecclesiastical authorities being challenged is already a pointer to some sort of freedom reigning in the institution contrary to the excesses of the era of the Roman Inquisition (Collins 2001; Dorr 1991). Also, the voicing out of the dissatisfaction is a progress made in the line of dialogue and possible reconciliation of the spotted vexatious situations. People are challenged to speak out their ill feelings about any unpalatable social setting, and suggest how best the distasteful situations can be redeemed. The dialogue coupled with positive actions enhances peace, for wherever the dialogue stops, there suspicion starts. Openness and ability to accept proven shortcomings also aid justice (Collins 2001; Dorr 1991).

Efforts made by the Church towards the promotion of peace and justice have yielded many good fortunes for the society and members of the Church, in particular. Today, people have grown in greater awareness of their rights and the need to ask for them when they are not recognised. Gone are those days when people ceded their rights to wicked individuals as a form of trying to maintain peace (Dorr 1991). Peace is now found in justice and no longer in unnecessary stomaching of acts of injustice and aggression. Priests of the Catholic Church have through the centuries of the social justice campaign helped people for self-actualisation, human development, dignity and freedom. 'The teaching of the Church on matters of justice and peace is an important contribution to the promotion of social justice in the world' (Dorr 1991).

Through the teaching, the gap between the rich and the poor has been considerably closed. The spirit of the gospel has influenced international debts that cripple the development of less privileged countries and hold them to sever hardships and hunger. We now understand that the world's riches are meant for universal consumption and to be evenly distributed to satisfy human need and not human greed. Oppressed people have been liberated through the teaching of the Church. Women, for instance, suffer lesser the effects of male chauvinism that characterised many cultures before the advent of the Church's teaching on the mutual ontological equality of man and woman from the point of view of their being human (Ezeanya 2018b:3). Other qualities of being stronger or weaker, first or last to be created have been made secondary, so that complementarities should prevail among the sexes instead of conflict and tussle for superiority (Ezeanya 2018b:7). The same is the case with the issues of racism, infringement on human rights, in general, and the proper handling of refugees (Dorr 1991; Suleiman 2016).

The Church through the priests has also looked into the structure of salary for workers and the problems posited by unemployment and teaches the principle of just wages and concern for the unemployed. This has made several proprietors and employers to consider the wages to be paid to the employees so as to not usurp their sweat for a slave labour, while each country schemes out policies to handle the plight of the unemployed (Bianchi \& Reuther 1992; Suleiman 2016:3). Violence, disarmament and environmental neglect have received the Church's active attention, such that different countries and the comity of nations today take them seriously. Population control and adequate family planning have been freed, among the faithful, from the negative propaganda of some selfish nations. These have been laudable achievements so far.

Priests have also championed the success of the Church in building up a joint relationship with the State, and through that joint effort the humankind who belongs both to the two stakeholders is holistically developed (Akukwe 1988). This activity, however, has to be encouraged and greased constantly for a continued progress of the work towards human development. Akukwe presented a report of how Onitsha Archdiocese in Nigeria had actually engaged in a social welfare activity to help the disabled people in the district. The diocese provided social amenities to them and fed them well, yet the number of the disabled people kept on diminishing until the programme was rendered unnecessary to continue. On interview, the disabled people confessed that they were taken care of very well, but needed a further security from the general society that would take care of the 
future of their children and other obligations they were faced with, and hence, they decided to quit the camp for the streets (Akukwe 1988).

This shows that humankind is always in need of freedom that has to flow from their rights. The people placed under charity of the diocesan 'Operation Limb-Giver' organisation were not satisfied with merely receiving certain 'hand to mouth' gifts from the organisation, but actually wanted the wider society to reflect the justice that would ensure their holistic provision from the commonwealth (Ezeanya 1998:13). They knew that the beggar has no choice and refused to remain in the condition of swallowing the request for the provision of certain needs, which would be the case if they continued to stay in the camp. They rather preferred to go out to the streets to take to begging, as that would pay them better in the provision of their needs. The Igbo proverbially say that Onye jere iku nwa o buru na nwa o jere $i k u$ anwuola, ihe chere ya bu inachigha-azu (the person who went to nurse a baby only to discover the baby dead, has no other job than to go back). With the evacuation of the centre by the disabled people, the activities of the centre closed up and the personnel workers had to go back to their tents (Ezeanya 1998:15).

Some scholars gathered to discuss how the Church can better address the proclamation of the Second Vatican Council that the Church is the 'People of God'. They approached the issue from the view of encouraging more participatory and democratic Church whereby the door of reforms opened with the Second Vatican Council may be widened all the more (Bianchi \& Reuther 1992). It was recommended that the ecclesiology of the Church has to be carefully adapted to the official Catholic Social Teaching in matters of social justice and respect of human rights. The ideal presented in the 1971 document of the world synod of bishops, Justitia in Mundo (on justice in the world), is to be followed consciously, whereby it is expected that anyone who ventures to speak to people about justice must first be just in their eyes. This yardstick will find expression especially in the right of workers to suitable livelihood, adequate security of life and property, and the right to fair trial and respect of people's integrity (Bianchi \& Reuther 1992). The call above is mainly directed to priests who are already in the struggle to ensure peace and social justice. It highlights the need for a greater implementation of the social agenda of the Second Vatican Council through creation of awareness to the rights of people to justice and peace both in the Church and in the secular society. It challenges the Church to champion the cause of justice starting from its own fabrics so as to have greater integrity when it confronts the civil society with the same demand.

\section{Evaluation and conclusion}

Everybody looks upon priests to play a major role in the peace and tranquillity of the human society, because they remain the religious link between God and humanity. They are the custodians and voice of the public conscience. Ever since Pope Leo XIII in his Rerum Novarum boosted the Church's involvement in the social action as actualised in the peace and social justice activities, priests are more and more reminded of their duty towards bettering even the temporal order of the society as a side of the coin with the spiritual in extending a holistic salvation to people. Keeping silent over people's unjust plight for whatever reason is, therefore, reckoned as a neglect of the duty incumbent on the priests (Ezeanya 1998:14).

Over the years, aggression against priests in different ways has tried to silence many from living out fully their demand of promoting peace and social justice among people, especially when there is the danger that their action might expose them to the vulnerability of attacks from violent people. Some priests had been murdered by armed criminals in the presbyteries on account of their witnessing to the gospel truth. Others have continued to receive threats of molestation and death for the same reason. Conflict remains the same everywhere but the nature, content and cause differ from one place to another. Wherever the conflict exists, the need for its resolution is always felt.

The Second Vatican Council in the Decree on the Ministry and Life of Priests (Presbyterorum Ordinis, 6.) while giving the priests their role as leaders of the people of God encourages them not to be servants of any human ideology or party but to be focused on leading the humankind to a holistic freedom of body and soul. In the Pastoral Constitution on the Church in the Modern World priests are urged to work with the faithful in dialoguing with the whole world so that there may be 'unity in what is necessary, freedom in what is doubtful and charity in everything' (Ezeanya 1998:15). The glory of God and human salvation is to be pursued rather than the satisfaction of the imperial wish of human leaders.

All these tend to show that the obligation on priests to ensure peace and social justice in the world is a heavy one. The review of their involvement in the arduous agenda of the peace and social justice action has shown how far efforts have gone into its progress. We have seen how priests can get to the grassroots to foster its success in more concrete terms. The target is not just to console the dejected of the society over the neglect of the leaders but more than that there is the thrust of the actions that would get both the leaders in government and the populace to know their respective duties and be compelled to do them. Priests should always be conscious of the fact that their success should not depend on the force of armament or coercion but on the grace of God that protects them from forces of the wicked perpetrators of discord and injustice. With this understanding, they should not lack in prayer even as they do their utmost in the struggle that has both divine and human kudos.

\section{Acknowledgements}

The authors thank Dr MacPerson Nnam for his guiding support during the article preparation. 


\section{Competing interests}

The authors declare that they have no financial or personal relationships that may have inappropriately influenced them in writing this article.

\section{Authors' contributions}

O.C.P.E. and B.O.A. contributed in the conception, drafting, proofreading and approval of the manuscript.

\section{Ethical considerations}

This study followed all ethical standards for research without any direct contact with human or animal subjects.

\section{Funding information}

This research work received no specific grant from any funding agency in the public, commercial or not-for-profit sectors.

\section{Data availability}

Data sharing is not applicable to this article as no new data were created or analysed in this study.

\section{Disclaimer}

The views and opinions expressed in this article are those of the authors and do not necessarily reflect the official policy or position of any affiliated agency of the authors.

\section{References}

Achunike, H.C., 2008, 'Religious practices in Nigeria as source of social conflict', Journal of Liberal Studies 12 (1\&2), 286-295.

Ajah, B.O., 2018, 'Educational training of inmates in Awka and Abakaliki prisons, Nigeria', International Journal of Criminal Justice Sciences 13(2), 299-305.

Ajah, B.O., Ajah, A.I. \& Obasi, C.O., 2020a, 'Application of virtual reality (VR) and augmented reality (AR) in the investigation and trial of Herdsmen terrorism in Nigeria', International Journal of Criminal Justice Sciences 15(1), 1-20.

Ajah, B.O., Dinne, C.E. \& Salami, K.K., 2020b, 'Terrorism in contemporary Nigerian society: Conquest of Boko-Haram, myth or reality', International Journal of Criminal Justice Sciences 15(1), 312-324.

Ajah, B.O., Nnam, M.U., Ajah, I.A., Idemili-Aronu, N. \& Onyejegbu, D.C., 2021, 'Investigating the awareness of virtual and augmented realities as a criminal justice response to the plight of awaiting-trial inmates in Ebonyi State, Nigeria', Crime, Law and Social Change 76, 1-9. https://doi.org/10.1007/s10611-021-09988-5

Ajah, B.O., Uwakwe, E.E., Nwokeoma, B.N., Ugwuoke, C.O. \& Nnnamani, R.G., 2020c, 'Ameliorating the plight of awaiting-trial inmates in Ebonyi State, Nigeria through
reasonable bail condition', Pertanika Jounal of Social Sciences \& Humanities 28(4), 2897-2911. https://doi.org/10.47836/pjssh.28.4.22

Ajah, B.O. \& Okpa, J.T., 2019, 'Digitization as a solution to the problem of awaiting-trial inmates in Ebonyi State, Nigeria', International Journal of Criminal Justice Sciences $14(2), 199-207$.

Ajah, B.O. \& Onyejegbu, D.C., 2019, 'Neo-economy and militating effects of Africa's profile on cybercrime', International Journal of Cyber Criminology 13(2), 326-342.

Ajah, B.O. \& Ugwuoke, C.O., 2018, 'Juvenile justice administration and child prisoners in Nigeria', International Journal of Criminal Justice Sciences 13(2), 438-446.

Akasike, C., 2018, 'Pastor remanded for killing pregnant girlfriend, two others', Punch Newspaper, 27 February, p. 9.

Akubo, J., 2018, 'Why I killed prostitute for ritual, by Kogi pastor', The Guardian Newspaper, 26 June, p. 11.

Akukwe, F., 1988, Towards a new society, Directorate of Social Services Archdiocese of Onitsha, Onitsha.

Anthony, E.O., Obasi, C.O., Obi, D.O., Ajah, B.O., Okpan, O.S., Onyejegbu, C.D. et al. 2021 , 'Exploring the reasons for perennial attacks on churches in Nigeria through 2021 , 'Exploring the reasons for perennial attacks on churches in Nigeria through
the victims' perspective', HTS Teologiese Studies/Theological Studies 77(1), a6207. https://doi.org/10.4102/hts.v77i1.6207
Areh, C.E., Onwuama, E.M. \& Ajah, B.O., 2020, 'Social consequences of wife-battering in Ogbaru and Onitsha North Local Government Areas of Anambra State, Nigeria', FWU Journal of Social Sciences 14(4), 80-92. https://doi.org/10.51709/FW12727 Arinze, F. (ed.), 1990, Gospel to society, Optimal Computer Solutions, Nsukka.

Armah, A., 1975, The beautiful ones are not yet born, Cox \& Wyman, London. Berger, K. (ed.), 1989, Sacramentum Mundi, vol. 3, Sheffield Academic Press, Sheffield. Bianchi, E. \& Reuther, R., 1992, A democratic Catholic church, Crossroad Publication Company, New York, NY.

Collins, P., 2001, From inquisition to freedom, pp. 7-13, Continuum, VII-Crossroad Pub., London.

Dorr, D., 1991, The social justice agenda, Gill and Macmillan, Dublin.

Enweonwu, O.A., Ugwu, I.P., Onyejegbu, D.C., Areh, C.E. \& Ajah, B.O., 2021, 'Religious fanaticism and changing patterns of violent Crime in Nigeria', International Journal of Criminology and Sociology 10, 1378-1389. https://doi.org/10.6000/1929 4409.2021.10.158

Eze, O.J., Ajah, B.O., Nwonovo, O.S. \& Atama, C.S., 2021, 'Health sector corruption and COVID-19 outbreak: Evidence from Anambra and Enugu States, Nigeria', Journal of Contemporary African Studies 39, 1-13. https://doi.org/10.1080/02589001.2021.1 921129

Eze, O.J., Obi, D.O. \& Ajah, B.O., 2020, 'Nigerian criminal justice system and victims of crime neglect in Enugu Urban', FWU Journal of Social Sciences 14(3), 41-53. https://doi.org/10.51709/FW1272J/fall2020/4

Ezeanya, P., 1998, Unveiling the enigma of death, p. 19, Coop Production, Enugu.

Ezeanya, O.C.P., 2014, Christian retreat \& genealogical healing, pp. 152-177, 244-264, Christus Doorways Ltd, Enugu.

Ezeanya, O.C.P., 2018a, Halos of grace, pp. 172-174, Christus Doorways Ltd., Enugu.

Ezeanya, O.C.P., 2018b, Igbo women at conflict situations: Rewriting the malechauvinistic narrative of valour', being a paper delivered at a conference on
May 8, 2018 to May 9, 2018 'Women and the Nigeria - Biafra War' (Women and May 8, 2018 to May 9, 2018 'Women and the Nigeria - Biafra War' (Women and organized by the Conflicts and Gender Rights Research Forum, Held at Ambassador Inn at Marquette, Milwaukee, Wisconsin, May 8-9, 2018

Iheanacho, N.N., 2009, 'A critical look at Contemporary Nigerian Christianity', International Journal of Theology \& Reformed Tradition 1, 104-117.

John Paul II, 1992, The Catechism of the Catholic Church, Vatican City, Libreria Editrice Vaticana, Nos. 1262, 1546-1547, 1591.

John Paul II, 1995, Ecclesia in Africa, pp. 51, 105, Pauline Pub, Nairobi.

Muhammed, I., Ismaila, A.B. \& Bibi, U.M., 2015, 'An assessment of farmer pastoralist conflict in Nigeria using GIS', International Journal of Engineering Science Invention 4, 23-33.

Nnam, M.U., Ajah, B.O., Arua, C.C., Okechukwu, G. \& Okorie, C.O., 2019, 'The war must be sustained: An integrated theoretical perspective of the Cyberspace-Boko Haram terrorism Nexus in Nigeria', International Journal of Cyber Criminology 13(2), 379-395.

Nnamani, G.R., Ilo, K.O., Onyejegbu, D.C., Ajah, B.O., Onwuama, M.E., Obiwulu, A.C. et al., 2021, 'Use of noncustodial measure and independent monitoring body as panacea to awaiting-trial problems in Ebonyi State, Nigeria', International Journa of Criminal Justice Sciences 16(1), 51-63.

Nwaigbo, F. (ed.), 2000, Jesus Christ the food of life, The Catholic Institute of West Africa, Port Harcourt.

Obegolu, C., 1999, Free and fair elections in Nigeria, Jimken Press, Enugu.

Odumegwu-Ojukwu, E., 1989, Because I am involved, Spectrum, Ibadan.

Okafor, K. \& Onebunne, J., 1996, Nnadiebube, Pymonak Publishers, Enugu.

Okpa, J.T., Ajah, B.O. \& Okunola, R.A., 2018, 'Religious fundamentalism and sustainable development in Nigeria: Understanding the intricacies', Journal of Religion and Theology 2(2), 12-18.

Onyejegbu, D.C., Onwuama, E.M., Onah, C.I., Okpa, J.T. \& Ajah, B.O., 2021, 'Special courts as Nigerian Criminal Justice response to the plight of awaiting trial inmates in Ebonyi State Nigeria' International Journal of Criminology and inmates in Ebonyi State, Nigeria', International Journal of Criminology and
Sociology 10, 1172-1177. https://doi.org/10.6000/1929-4409.2021.10.136

Otu, S.E., Nnam, M.U. \& Uduka, U.K., 2018, 'Voices from behind the bars: Kidnappers' natural self-accounting views, perceptions, and feelings on kidnapping in the Southeastern States of Nigeria', Journal of Forensic Psychology Research and Practice 18(3), 254-279. https://doi.org/10.1080/24732850.2018 Research
.1471649

Rahman, N.F.A. \& Khambali, K.M., 2013, 'Religious tolerance in Malaysia; problems and challenges', International Journal of Islamic Thought 3, 81-91. https://doi. org/10.24035/ijit.03.2013.007

Sagay, I., 2000, Nigerian law of contract, Spectrum Books, Ibadan.

Suleiman, K.O., 2016, 'Religious violence in contemporary Nigeria: Implications and options for peace and stability order', Journal for the Study of Religion 29(1), 85-103.

Ugwuoke, C.O., Ajah, B.O. \& Onyejegbu, C.D., 2020, 'Developing patterns of violent crimes in Nigerian democratic transitions', Aggression and Violent Behavior 53 1-8. https://doi.org/10.1016/j.avb.2020.101457

Zenn, J., 2017, 'Demystifying al-Qaida in Nigeria: Cases from Boko Haram's founding, launch of jihad and suicide bombings', Perspective on Terrorism $11(6), 173-189$ 